\title{
어음명료지수의 측정과 적용
}

\section{Measurements and Applications of the Speech Intelligibility Index (SII)}

\author{
${ }^{1}$ 한림대학교 일반대학원 언어병리청각학과, ${ }^{2}$ 한림대학교 자연과학대학 언어청각학부, 청각언어연구소 \\ 김건구 ${ }^{1} \cdot$ 진인기 ${ }^{2}$ \\ Gun-Gu Kim ${ }^{1}$ and $\mathrm{In}-\mathrm{Ki} \mathrm{Jin}^{2}$ \\ ${ }^{1}$ Department of Speech Pathology and Audiology, Graduate School, Hallym University, Chuncheon \\ ${ }^{2}$ Division of Speech Pathology and Audiology, Research Institute of Audiology and Speech Pathology, \\ College of Natural Sciences, Hallym University, Chuncheon, Korea
}

\begin{abstract}
Speech Intelligibility Index (SII) is a model that predicts speech intelligibility based on a person's hearing thresholds and audible speech cues in given frequency bands. The SII is able to predict how loss of audibility due to hearing loss affects intelligibility of speech. Thus, the SII has been applied clinically in evaluation and fitting for hearing aids to quantify how much audibility is compensated by amplification. Although the SII known as Articulation Index was first introduced during the $20^{\text {th }}$ century, calculation methods and aspects of the SII have been continually refined and developed for clinical use. This article provides (1) a brief history of the SII, (2) a view of components and calculation methods of the SII, (3) a review of applications for clinical use, and (4) a discussion of limitations and aspects that need to be considered for clinical applications in future.
\end{abstract}

Key words: Articulation index, Speech intelligibility index (SII), Hearing aids, Band-audibility function (BAF), Band-importance function (BIF)

\section{INTRODUCTION}

조음이론모델(the model of articulation theory) 은 전기음향학적인 조건 속에서 다양한 통신기기를 통해 어음이 정확하게 전달되는 정도를 예측하기 위

논문접수일: 2015년 4월 17일

논문수정일: 2015년 5월 20일

게재확정일: 2015년 6월 24일

교신저자: 진인기, 강원도 춘천시 한림대학길 1

한림대학교 자연과학대학 언어청각학부

Tel: (033) 248-2221, Fax: (033) 256-3420

E-mail: inkijin@hallym.ac.kr
하여 Bell Telephone Laboratories에서 제안하였다 (French \& Steinberg, 1947). 특히 조음이론모델은 어 음의 주파수중요함수(frequency importance function) 와 가청어음신호(audible speech cues)를 이용하여 전달되는 어음의 품질을 평가했는데, 청각학에서는 조음이론모델의 일부 구성 요소를 어음인지도를 예측 하는 모델의 개발에 활용하였다. 초기의 어음인지도 예측 모델은 가청어음신호와 어음명료도와의 관계를 정량화하기 위해 개발되었고, 조음지수(articulation index)라는 이름으로 사용하였다(Amlani et al., 2002). 조음지수는 주어진 주파수대역에서의 소음의 강도를 
고려하여, 어음에 대한 어음명료도를 예측하는 모델 이다(Kryter, 1962). 하지만 조음지수는 어음인지도 를 예측하는 지표로서 사용되었지만, 이름의 의미가 청력(audition)보다는 조음(articulation)의 개념에 가까워 용어의 혼란을 없애기 위해 많은 연구자들의 견해에 따라 가청지수(Audibility Index)로 용어를 변 경 하였다(Killion et al., 1993; Studebaker, 1992). 이후 1997년에 미국국가표준기구(American National Standard Institute, ANSI)에서 가청지수에 대한 표 준화연구를 진행하였고, 가청지수에서 어음명료지수 (speech intelligibility index, SII)로 명칭을 변경하 여 현재까지 청각학의 여러 분야에 적용하여 활용하 고 있다(ANSI, 1997/R2012).

어음명료지수에서 어음의 가청영역은 어음의 인지 도를 예측하는데 매우 중요한 역할을 하는데, Dunn \& White(1940)는 $1 \mathrm{~Hz}$ 마다 평균신호음압강도(average sound pressure level)를 측정하여 어음의 역동범위 (dynamic range)를 제안 하였다. 이때 사용된 통합 시간(integration time)은 $125 \mathrm{msec}$ 이었다. Dunn \& White(1940)는 영어의 어음은 주파수별로 $30 \mathrm{~dB}$ 의 역동범위를 가지고 있다고 제안 하였는데, 이는 장기 평균어음스펙트럼(long-term average speech spectrum) 을 기준으로 최대값은 $+12 \mathrm{~dB}$, 최소값은 $-18 \mathrm{~dB}$ 에 해당하는 범위를 의미했다. Dunn \& White(1940)가 제안한 $30 \mathrm{~dB}$ 의 역동범위는 이후 여러 연구자들로부 터 검증되어 어음명료지수(조음지수)에서 어음인지도 를 가장 정확하게 예측하는 범위로 사용하여 왔다 (e.g., French \& Steinberg, 1947; Kryter, 1962; Pavlovic \& Studebaker, 1984). 하지만 조음지수에 서 어음명료지수로 표준화 과정이 이루어 질 때, 30 $\mathrm{dB}$ 의 역동범위는 $+12 \mathrm{~dB}$ 에서 $-18 \mathrm{~dB}$ 가 아닌, 장기 평균어음스펙트럼을 기준으로 $\pm 15 \mathrm{~dB}$ 로 수정하였 다. 그 이유는 어음명료지수로 명칭이 바뀔 때, 소음 하 상황에서의 어음인지도를 예측하는 과정에서 \pm 15 $\mathrm{dB}$ 범위의 역동범위가 더욱 정확한 예측값을 산출했 기 때문이다(ANSI, 1997/R2012).

어음명료지수는 청각학 분야의 증폭기기 관련 분 야의 임상과 연구에서 여러 방식으로 사용하고 있다.
어음명료지수는 임상에서 주로 보청기의 착용 전과 후 의 예후를 어음인지도의 변화를 통해 예측하는 모델로 사용하고 있으며(Rankovic, 1991; Studebaker et al., 1993), 어음명료지수의 복잡한 계산과정을 간소화 하여 제작된 Count-the-Dot Audiogram (Mueller \& Killion, 1990)은 임상에서 환자에게 보청기의 착용효과를 설 명하는 효율적인 상담도구로 이용하고 있다. 또한 어 음명료지수가 어음인지도를 예측할 때 고려하는 요 소인 주파수별 공헌도와 가청영역과의 상관관계는 보청기의 적합에서 주파수별 이득에 대한 필요성을 설명하는 중요한 개념적 근거를 제공 하였다(Humes, 1986). 그 이후, 어음명료지수를 선형보청기의 주파 수별 이득의 특성을 결정하는데 사용하였고(Rankovic, 1991), 비선형 보청기적합공식 중 하나인 NAL-NL1 (National Acoustics Labs, Non-Linear, version 1)에서도 적용하였다(Dillon, 1999).

어음명료지수는 주파수별 특성과 어음의 가청영역 에 대한 개념을 포함하고 있어서 보청기의 착용효과 와 적합공식의 개발에 효과적으로 적용될 수 있기 때 문에 임상에서 어음인지도를 예측하는 모델로서 중요 한 역할을 할 수 있다. 그러나 어음명료지수는 매우 복잡한 계산방법과 절차로 구성되어 있기 때문에, 어 음명료지수에 대한 이해를 돕고자 본 종설에서는 크 게 3 가지의 주제로 나누어 설명하고자 한다. 첫 번째 로 어음명료지수의 구성요소들에 대한 정의와 산출방 법에 대해 기술하였다. 다음으로 어음명료지수가 사 용되는 구체적인 사례에 대하여 열거하였다. 마지막 으로 어음명료지수가 더욱 정확한 예측을 위하여 향 후 고려되어야 할 요소들을 고찰에서 서술하였다.

\section{A REVIEW OF COMPONENTS AND CALCULATION METHODS OF THE SII}

어음명료지수는 다음과 같은 식으로 표현 할 수 있다. [식-1]에서, $K$ 는 주파수대역(frequency band) 의 전체 숫자를, $A_{k}$ 는 주파수대역 $k$ 에서의 대역가 청함수(band-audibility function, BAF)을, $I_{k}$ 는 주 
파수대역 $k$ 에서의 주파수중요함수(band-importance function, BIF)을 의미한다(ANSI, 1997/R2012). 따 라서 어음명료지수는 각 주파수대역별 대역가청함수 와 주파수중요함수의 곱으로 계산되어 진 후, 각 주 파수대역에서 산출한 값의 합으로 총 어음명료지수 값이 결정된다. 이때, 총 어음명료지수는 0 (최소값) 과 1(최대값) 사이의 범위로 나타낼 수 있다.

$$
S I I=\sum_{k=1}^{K} A_{k} I_{k},
$$

[식-1]에서 보여지는 것과 같이, 어음명료지수는 두 가지 요소로 구성되어 있다. 첫 번째 요소는 대역 가청함수다. 대역가청함수는 주어진 주파수대역에서 청자의 청력역치를 기준으로 청자가 들을 수 있는 어 음에너지의 비율을 나타낸다(ANSI, 1997/R2012). 대 역가청역치는 [식-2]와 같이 표현할 수 있다.

$$
A_{i}=\left(S N R_{i}+K\right) / D,
$$

$S N R_{i}$ 는 주파수대역 $i$ 에서의 신호대잡음비(signal -to-noise ratio, $\mathrm{SNR}$ )를 데시벨(dB) 단위로 표현 한 값을 의미하고, $K$ 는 어음강도의 최대값에서 어음 의 실효치 레벨(speech root-mean-square level)을 뺀 값을 의미하며, $D$ 는 어음의 역동범위를 나타낸 다. 영어버전의 대역가청함수의 경우, 어음의 실효치 레벨을 기준으로 $\pm 15 \mathrm{~dB}$ 로 표준화하여 사용되고 있 으며(ANSI, 1997/R2012), 이 범위는 다양한 SNR 상 황에서 어음의 인지도를 측정하고 표준화된 어음의 역동범위를 제안한 Studebaker et al.(1993)의 연구 결과를 기반으로 채택 하였다. 즉, 영어의 경우, 어 음의 역동범위는 전 주파수에 걸쳐 $30 \mathrm{~dB}$ 이며, 대역 가청역치의 값은 0 과 1 사이에서 결정된다. 0 은 청자 의 청력역치가 어음의 역동범위를 벗어나 어떠한 어 음도 들을 수 없음을 의미하고, 1 은 청자의 청력역치 가 모든 주파수대역에서 어음의 역치보다 충분히 좋 아 모든 어음을 다 들을 수 있음을 의미한다.

두 번째 요소는 주파수중요함수다. 주파수중요함
수는 어음인지도에 대해서 다른 주파수대역과 비교할 때 중요한 정도를 비율로 나타낸 지표를 말한다 (ANSI, 1997/R2012). 즉, 각 주파수대역의 중요도는 전체중요도를 1 로 고정하고 상대적인 중요도로 계산 되며, 각 주파수 대역에서의 중요도를 모두 더하면 그 합은 1이 된다. 영어문장표를 기준으로 산출한 주 파수중요함수의 경우, $1,370 \mathrm{~Hz}$ (중심주파수)대역이 .1099(10.99\%)로 어음인지에 가장 큰 영향을 주고 있으며, $150 \mathrm{~Hz}$ (중심주파수)대역은 .0315, 2,900 $\mathrm{Hz}$ (중심주파수)대역은 .0646으로 주파수마다 다른 중요도를 가지고 있음을 확인 할 수 있다(Healy et al., 2013). 그리고 각 주파수대역의 중요도를 모두 더하면 그 합은 $1(100 \%)$ 이 된다.

주파수중요함수의 측정은 여러 단계의 절차와 반복 적인 접근법을 사용한다(French \& Steinberg, 1947; Studebaker \& Sherbecoe, 1991). 첫 번째 단계는 SNR 을 이용한 다양한 소음의 조건과 여러 주파수대역을 필터링(filtering)을 이용해서 나눈 다음, 다양한 조건 속에서 어음인지도를 측정하는 것이다. 예를 들어, 이 경원 \& 김진숙(2012)은 단음절어표를 이용하여 $\mathrm{SNR}$ 은 $-10 \mathrm{~dB}$ 에서 $+8 \mathrm{~dB}$ 까지 $2 \mathrm{~dB}$ 간격으로 총 10 개, 필 터링은 총 13 개의 주파수 대역에서 어음인지도를 측 정하여 주파수중요함수를 구하였다.

다음 단계는 각 조건에서의 평균 어음인지도와 어 음명료지수 값의 대략적인 상관관계를 구하는 것이 다. 일반적으로 어음인지도는 백분율(0에서 100\%)에 서 지수(0에서 1사이)로 바꾸어 표시한다. 이때 그래 프를 통해서 두 지표의 대략적인 관계가 형성되는데 그래프를 부드럽게 표현하기 위해서 Studebaker \& Sherbecoe(1991)가 제안한 다음의 네 가지 법칙을 따르는 것이 일반적이다. 즉, (1) 하나의 SNR 그래프는 다른 SNR 그래프와 겹치지 않도록 한다. (2) 같은 SNR 조건에서 저주파수통과필터(low-pass filter)와 고주파수통과필터(high-pass filter) 사이에는 한 개 의 교차점만 있도록 한다. (3) SNR이 증가하면 어음 인지도는 증가하도록 한다. (4) 같은 $\mathrm{SNR}$ 조건에서 두 그래프는(low-pass \& high-pass filters) 최대한 비슷한 점수로 끝나도록 한다. 부드러운 곡선을 산출 
하기 위하여 예전에는 손으로 그리는 방법들이 사용 되었지만(Dunn \& White, 1940), 요즘에는 cubic spline curve fitting법과 같은 그래프산출법을 이용 하기도 한다(DePaolis et al., 1996).

세 번째 단계는 두 번째 단계에서 부드럽게 산출 한 그래프들을 기준으로 어음인지도와 상응하는 어음 명료지수를 구하는 것이다. 예를 들면, 가장 높은 SNR에서 산출한 두 곡선(low-pass \& high-pass filters)의 교차점은 어음인지에 가장 유리한 조건의 어음인지도를 100 점으로 보았을 때, 전체 어음인지도 의 $50 \%$ 에 해당하는 지점으로 볼 수 있으므로 .5 SII 에 상응하는 값으로 간주한다. 이와 같은 방법으로
수십개의 상응점을 찾아내고 이를 하나의 그래프로 표현한다. 그리고 해당 그래프의 사이값들을 가장 잘 추정할 수 있는 수학공식을 산출하는데 다음의 식이 가장 일반적으로 사용되고 있다(ANSI, 1997/R2012).

$$
S=\left(1-10^{-\frac{P A}{Q}}\right)^{N},
$$

[식-3]에서 $S$ 는 어음인지도, $P$ 는 화자와 청자의 발 화와 듣기능력의 숙련도(일반적으로 1 로 고정), $A$ 는 어 음명료지수 값을 나타내고, $Q$ 와 $N$ 은 곡선을 잘 나타 내기 위한 상수값(fitting constant)을 의미한다.

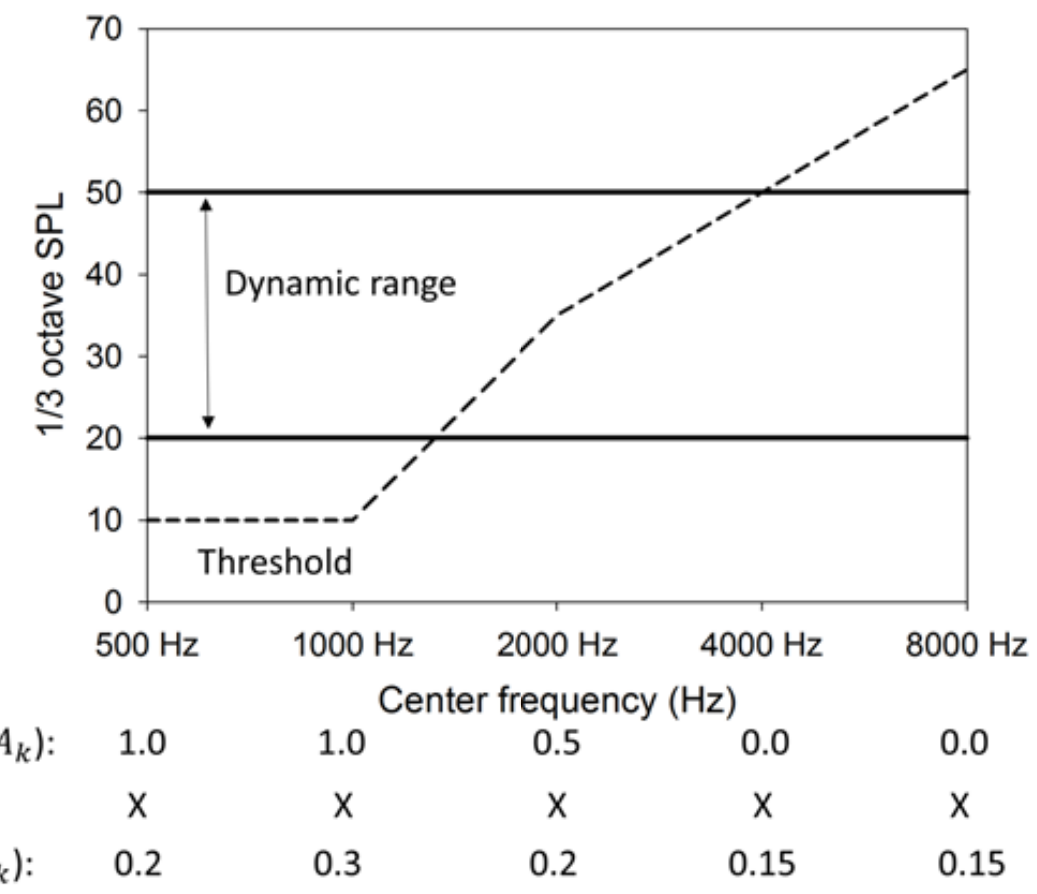

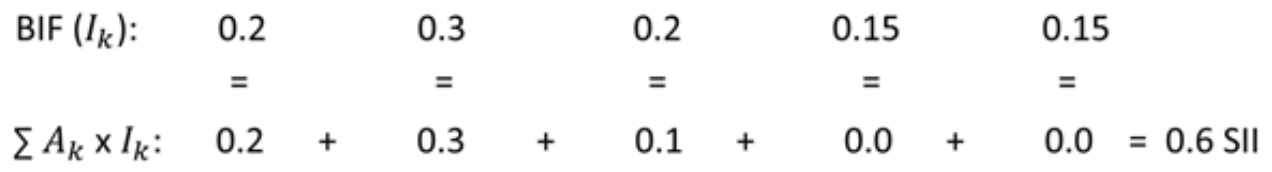

Figure 1. 어음명료지수(SII) 계산법의 예. 역동범위(dynamic range)를 $30 \mathrm{~dB}$ 로 설정하였고, 중심주파수(center frequency)를 기준으로 $500 \mathrm{~Hz}$ 부터 $8,000 \mathrm{~Hz}$ 사이의 5 개 주 파수대역을 예로 들음. 점선은 청력역치를 나타냄. 주파수중요함수(BIF)의 값은 임의로 설정함.

네 번째 단계는 [식-3]에서 역수방정식(inverse equation)을 이용하여, 어음명료지수 값(A)을 어음인 지도 $(\mathrm{S})$ 와 바꿔서 같은 식이 성립하도록 한 다음, 첫
번째 단계에서 구한 모든 평균어음인지도를 [식-3]의 역수방정식을 통해 상응하는 어음명료지수 값을 구한 다. 그럼 모든 평균어음인지도는 그에 상응하는 어음 
명료지수 값으로 바뀌게 되고 이는 각 주파수대역에 해당하는 값이라기 보단 이전 주파수대역에서의 어음 명료지수 값을 포함하는 누적분포로 나타난다. 이를 각 주파수대역별 어음명료지수 값으로 변화하기 위해 서 가장 높은 주파수대역의 값에서 한 단계 아래의 주파수대역의 값을 차감한다. 이와 같은 방법으로 각 주파수대역별 어음명료지수 값을 구한다.

다섯 번째 단계는 같은 SNR에서 동일한 주파수대 역별로 저주파수통과필터와 고주파수통과필터의 값 을 평균한다. 단, 한쪽의 값이 0 또는 0 보다 작을 경 우, 이는 양수인 다른 쪽의 값만 사용하여 구한다 (Studebaker \& Sherbecoe, 1991). 그 다음은 같은 주파수대역에 존재하는 모든 SNR 조건에서의 값들의 평균을 구한다. 그러면 각 주파수대역마다 하나의 통 합된 평균값을 가지게 되고 이를 누적분포로 만들어 가장 넓은 주파수범위의 값이 1 이 아니라면 이를 1 로 고정하고, 나머지 값들을 비율공식을 이용하여 상대 적인 비율로 나타낸다. 그리고 최대값이 1 로 바뀌어 진 누적분포값을 각 주파수별 값으로 바꾸면 최종 주 파수대역별 중요함수값을 얻을 수 있다.

Figure 1은 어음명료지수의 계산법에 대한 이해를 돕고자 예를 들어 설명하고 있다. 대역가청함수의 경
우, 어음의 역동범위와 청력역치의 비율로 그 값이 결정된다. 예를 들어, 청력역치가 어음역동범위 보다 좋으면 1 로 구해지고 $(500 \mathrm{~Hz} \& 1,000 \mathrm{~Hz})$, 청력역 치가 어음역동범위의 $50 \%$ 지점이라면, .5로 구해진 다 $(2,000 \mathrm{~Hz})$. 주파수중요함수 $(\mathrm{BIF})$ 는 각 주파수대역 별로 다른 중요도를 가지며 Figure 1에서는 임의의 값으로 설정하였다. 각 주파수대역별로 산출한 대역 가청함수값과 주파수중요함수값이 곱해지면, 각 주파 수대역별 어음명료지수 값이 결정되고, 모든 주파수 대역별 어음명료지수 값을 더하면 최종 어음명료지수 값( $.6 \mathrm{SII})$ 을 얻게 된다.

\section{A REVIEW OF APPLICATIONS FOR CLINICAL USE}

어음명료지수는 조용하거나 소음이 존재하는 환경 에서 난청이 어음인지에 주는 영향을 수치로 예측하 는 모델이다(Amlani et al., 2002). 임상에서 어음명 료지수는 주로 보청기의 적합효과 및 평가의 예측에 사용되고 있다. 본 종설에서는 어음명료지수가 임상 에서 적용되는 사례들을 소개 하고자 한다.

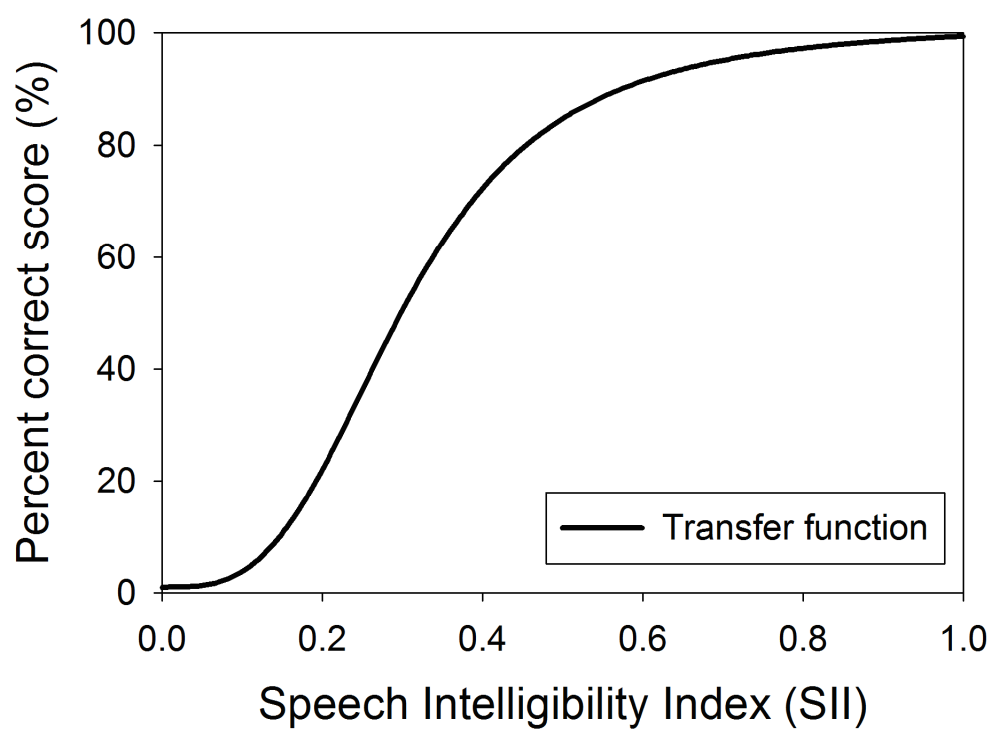

Figure 2. 임의의 값으로 제작된 전달함수 
어음명료지수는 어음인지도(\%)와 어음명료지수간의 상관관계를 나타내는 전달함수(transfer function)를 통하여 어음인지도를 예측 할 수 있다(e.g., DePaolis et al., 1996; Fletcher \& Galt, 1950; Studebaker $\&$ Sherbecoe, 1991). 이 전달함수는 보청기 착용 전 후에 따른 역치의 변화를 통하여 보청기의 예후를 예 측하는데 사용되고 있다. Figure 2는 임의의 값으로 제작된 전달함수이다(DePaolis et al., 1996). 예를 들어, 청자의 청력역치와 주파수중요함수 및 대역가 청함수를 통하여 얻은 어음명료지수가 보청기를 착용 하기 전에 .2 SII 였다면, 약 $25 \%$ 의 어음인지도가 예상 됨을 알 수 있다. 그리고 보청기 착용 후에 다 시 측정한 어음명료지수 점수가 .5 SII였다면, 약 $85 \%$ 의 어음인지도가 예상된다(Figure 2). 보청기 착 용 전후의 어음인지도의 변화를 보면 $25 \%$ 에서 $85 \%$ 로 약 $60 \%$ 의 증가를 확인 할 수 있다. 이 결과는 실 제 음장(sound field)에서 이루어지는 어음인지도검 사와의 신뢰도를 위해서도 사용되며, 실제 어음인지 도 측정에 어려움이 있는 아동이나 노인에게 적용되 어 보청기의 착용 효과를 예측하는 지표로 사용할 수 있다.

어음명료지수는 매우 복잡한 수식과 절차에 의해 서 구해지는데, 이를 간소화하여 환자와의 상담을 돕 는데 사용되기도 한다. Killion \& Mueller(2010)는 100 개의 점을 이용하여 주파수중요함수와 어음의 가 청영역을 청력도에 적용한 표를 제안 하였다. 각 주 파수의 중요도에 따라 점들의 수가 분포되고, 점들이 분포되어 있는 영역이 해당 주파수의 가청영역을 나 타낸다. 예를 들어, $250 \mathrm{~Hz}$ 의 경우에는 2 개의 점이 어음의 역동범위 내에 위치하고 있어 .02 SII를 나 타낸다. 그리고 $2 \mathrm{kHz}$ 의 경우에는 9 개의 점이 어음 의 역동범위 내에 분포하며 이는 .09 SII를 나타낸 다. 이 표(Count-the-Dot Audiogram)에 환자의 청 력역치가 표시되고, 역치를 기준으로 들을 수 있는 영역에(역치의 아래쪽) 위치하고 있는 점들의 수를 모두 더하면 어음명료지수 값을 얻을 수 있다. 그리 고 여기서 얻어진 값을 전달함수를 통해 어음인지도 를 예측 할 수 있다. 물론 이 표(Count-the-Dot
Audiogram)는 점들의 간격이 모두 일정하게 간소화 되어 있어서 실제 인지도에 영향을 미치는 가중치 (weighted value)가 고려되어 있지 않아 실제 어음 명료지수의 개념을 모두 포함한다고 할 수는 없으나, 환자에게 청력역치와 보청기의 예후를 어음인지도와 비교하여 상담할 때, 환자의 이해를 돕기 위한 유용한 도구로 사용되고 있다(Amlani et al., 2002; Killion \& Mueller, 2010).

또한 어음인지도는 보청기적합공식(hearing aid fitting prescription)에도 사용되고 있다. NAL-NL1 은 영어의 어음명료지수를 기반으로 제작된 보청기적 합공식이다(Dillon, 1999). NAL-NL1은 주파수별 이 득(frequency-gain characteristics)을 계산할 때, 어음명료지수에서 사용되고 있는 역동범위(dynamic range)을 기반으로 하고 있다. 최근에는 NAL-NL2 가 개발되어 가청영역 뿐만 아니라 최대출력이 보청 기 사용자로 하여금 불편한 소리로 듣지 않도록 유지 할 수 있는 이득곡선을 산출 하도록 고안된 적합공식 이 소개 되기도 했다(Keidser et al., 2011).

\section{DISCUSSIONS}

어음명료지수는 보청기의 예후를 예측할 수 있고, 보청기적합공식으로 쓰이고도 있어 임상적으로 매우 유용한 도구라고 할 수 있다. 하지만 임상에서 더욱 효과적인 적용을 위해서는 앞으로 보완해야 할 요소 들도 있다(e.g., Amlani et al., 2002; Jin et al., 2014; Wong et al., 2007). 본 고찰에서는 어음명료 지수가 더욱 정확한 인지도의 예측을 위해 앞으로 고 려해야할 요소들에 대해 제안 하고자 한다.

첫째, 어음명료지수의 정확도를 더욱 높이기 위해 서는 난청의 정도(degree)와 유형(type)을 고려한 계 산법이 적용되어야 할 것이다(e.g., Amlani et al., 2002; Kamm et al., 1985; Studebaker et al., 1997). Kamm et al.(1985)은 정상 청각군 5명과 경 도 및 중도 난청군 10 명을 대상으로 어음명료지수의 정확도를 측정하였는데, 두 그룹에서 모두 높은 정확 
도를 보였다고 보고 하였다. 그러나 Pavlovic(1984) 의 연구를 포함한 많은 연구들은 중도이상 난청군에 서는 어음명료지수의 정확도가 매우 저조하다고 보고 하였다(e.g., Dubno et al., 1989; Rankovic, 1991). 그 이유는 어음명료지수는 정상 청력인의 어음인지도 수행력과 어음의 역동범위를 기준하여 개발되었기 때 문에(ANSI, 1997/R2012), 고심도 난청군에서 주로 나타나는 탈감각(desensitization)과 같은 특성이 어 음명료지수의 계산법에 적용되지 못했기 때문이다 (Amlani et al., 2002). 와우의 탈감각 현상은 청각 역치에 비해 어음의 분별력이 비정상적으로 저하되는 현상을 말하며, 주로 고심도 난청군에서 나타난다 (Pavlovic et al., 1986). Fletcher \& Galt (1950)는 조음지수를 개발하는 시점에서, [식-3]에서 $P$ 라는 상수를 적용하여 화자와 청자의 발화와 듣기능력의 숙련도 정도를 측정하여 난청의 정도에 따른 예측을 달리 해야 한다고 제안 하였으나 뚜렷한 $P$ 값의 기준 에 대한 보고는 없었다. Ching et al.(2001)은 탈 감 각으로 인한 가청영역의 변화를 고려하는 계산법을 어음명료지수의 계산법에 적용하여 다양한 난청군을 대상으로 예측의 정확도를 측정 하였다. 그 결과, 고 심도 난청군에서 탈감각을 고려한 어음명료지수가 그 렇지 않은 어음명료지수에 비해 높은 정확도를 보였 다고 보고 하였으나, 급경사형태의 난청군에서는 여 전히 낮은 예측값을 보인다고 보고 하였다(Ching et al., 2001). 현재까지의 연구결과들을 종합해 볼 때, 어음명료지수는 정상 청각군, 경도 및 수평형 중도 난청군에서는 매우 높은 정확도를 보이고 있으나, 고 도이상의 난청군이나 급경사형 난청군에서는 다소 저 조한 예측값을 보이고 있다. 따라서 앞으로 개발될 어음명료지수는 난청의 정도와 형태를 고려한 계산법 이 개발 되어야 할 것이다.

또한 어음명료지수는 연령(age)에 따른 계산법이 적용되어야 한다(e.g, Abel et al., 2000; Dubno et al., 1984; Hargus \& Gordon-Salant, 1995). 노인 들의 청력손실은 노화로 인한 청각민감도(auditory sensitivity)의 감소(Humes \& Roberts, 1990; Humes et al., 1994) 뿐만 아니라, 말초 처리과정의 노화
(Hargus \& Gordon-Salant, 1995; Jerger et al., 1989; Schum et al., 1991), 중추신경계의 노화(Humes et al., 1996) 에서도 기인한다. Studebaker et al.(1997)은 단음절어표를 이용하여 20 대에서 80 대 사이의 연령 군을 7 개 그룹으로 나누어 연령대별로 어음인지도를 측정하였다. 그 결과, 유사한 청력역치를 가진 참여자 들 중에서, 70 대 이상의 참여자들이 다른 참여자들에 비해 낮은 어음인지도수행력을 보였다고 보고 하였다. 이는 어음명료지수의 개발에 있어, 연령에 의한 차이 또한 고려해야 한다는 것을 시사한다.

어음명료지수는 또한 언어적 특성에 따라 그 특징 이 달라질 수 있기 때문에 해당 언어에 기반하여 제 작 되어야 한다(Jin et al., 2014; Wong et al., 2007). Wong et al.(2007)은 광동어(Cantonese)를 기반으로 주파수중요함수를 구했는데, 영어의 주파수 중요함수(DePaolis et al., 1996)와 다른 결과를 보 였다. 예들 들어, 광동어의 경우 가장 중요도가 높은 중심주파수대역은 $1,600 \mathrm{~Hz}$ 주변이었고, $355 \mathrm{~Hz}$ 이 하의 저주파수영역의 어음명료지수 값은 .136이었으 나, 영어의 경우 가장 중요도가 높은 중심주파수대역 은 $2,000 \mathrm{~Hz}$ 부근이었고, $400 \mathrm{~Hz}$ 이하의 저주파수 영역의 어음명료지수 값은 .0464이었다. Wong et al. (2007)은 광둥어의 주파수중요함수에서 저주파수 영역이 영어에 비해 더 중요할 수 있는 이유로 성조 (tonal characteristic)를 예로 들었다. 광동어의 경 우, 성조로 뜻을 구분해야 하는 어휘들이 다수 존재 하는데 이를 구별하기 위해서는 주로 저주파수에서 이루어지는 성조의 변화가 중요한 요소이기 때문에 주파수중요함수에서 저주파수영역에 가중치가 더해진 이유이며, 영어(non-tonal language)는 상대적으로 성조를 거의 쓰지 않기 때문에 저주파수영역에 가중 치가 더해지지 않았다고 설명하였다(Wong et al., 2007).

한국어 또한 영어나 광동어와는 다른 어음명료지 수의 예측이 예상된다(Jin et al., 2014). Jin et al. (2014)은 한국어, 영어, 광동어의 어음의 역동범위 를 비교하였다. 그 결과, 한국어의 역동범위는 중심 주파수를 기준으로 $455 \mathrm{~Hz}$ 이하에서 타 언어들에 비 
해 좁은 역동범위를 보였으며, $455 \mathrm{~Hz}$ 에서 $4,050 \mathrm{~Hz}$ 에 이르는 중주파수 범위에서는 영어의 역동범위가 가장 좁았고, $4,050 \mathrm{~Hz}$ 이상의 고주파수 영역에서는 한국어와 광동어의 역동범위는 유사했으나 영어의 역 동범위는 상대적으로 타 언어들에 비해 넓은 역동범 위가 나타났다(Jin et al., 2014). 또한 음절의 구조 에서도 한국어는 타언어와 다른 차이를 보이고 있다. 예를 들어, 영어의 음절구조는 가장 짧은 경우에 /a/ 와 같이 하나의 모음으로 음절을 이룰 수 있으나, /strength/와 같은 음절 에서는 자음의 수가 모음에 비해 현저히 많은 음절구조를 보인다. 반면에 한국어 는 /가/, /각/, /각도/와 같이 자음과 모음의 수가 영어에 비해 비슷하게 유지되는 구조를 가지고 있다 (Kim \& Pae, 2007; Smit, 2007). 이는 영어에 비해 상대적으로 모음의 사용이 많은 한국어가 저주파수의 에너지를 더 많이 사용할 가능성이 있으며, 이는 한 국어가 영어에 비해 저주파수 영역이 어음인지도에 미치는 영향이 클수도 있다는 가정을 가능하게 만든 다. 위의 연구결과들에 기준 했을 때, 언어적인 특성 은 어음의 역동범위나 주파수중요함수에 영향을 줄 수 있다. 그리고 어음의 역동범위나 주파수중요함수 는 어음명료지수에서 매우 중요한 요소이기 때문에 보청기의 적합과 평가에서 어음명료지수를 사용할 때 는 해당 언어에 기반한 어음명료지수가 사용되어야 정확한 어음인지도를 예측 할 수 있을 것이다.

\section{CONCLUSIONS}

통신기기에서 정확한 말소리의 전달정도를 예측하 기 위해 조음지수로 개발된 어음명료지수는 지속적으 로 한계점을 극복하며 현재는 청각학에서 많은 임상 적인 의의를 가지며 사용되고 있다. 하지만 영어권 나라에서는 보편적으로 사용되고 있다 할지라도, 영 어에 기반한 어음명료지수만이 현재 통용되어 사용되 고 있기 때문에, 영어와 다른 언어적 및 음향적 특성 을 보이는 한국어를 주로 사용하고 있는 한국에서는 그 적용과 효용성에 대하여 물음표를 가질 수 밖에
없었다. 최근의 연구결과(Jin et al., 2014)는 한국어 에 기반한 어음명료지수의 개발이 필요함을 보여주고 있는데, 만약 한국어에 기반하여 표준화된 대역가청 함수와 주파수중요함수가 개발된다면 한국인에게 최 적화된 어음명료지수를 개발할 수 있을 것이다. 더불 어 위에서 언급되었던 다른 한계점(탈 감각 현상, 연 령에 따른 민감도의 변화)이 한국어의 어음명료지수 의 개발에서 고려된다면, 보청기적합과 평가에서 기 존 영어기반의 어음명료지수보다 더 활용성 높게 사 용 될 수 있을 것이라 기대한다.

중심단어: 대역가청함수, 보청기, 어음명료지수, 조음지수, 주파수중요함수

\section{ACKNOWLEDGEMENTS}

본 종설에서 임상적 적용에 대한 조언을 주신 Kathryn H. Arehart와 James M. Kates 교수님께 감사드립니다.

\section{REFERENCES}

이경원 \& 김진숙. (2012). 한국 단음절어의 주파수중 요기능 연구. 청능재활, 8(1), 24-33.

Abel, S. M., Sass-Kortsak, A., \& Naugler, J. J. (2000). The role of high-frequency hearing in age-related speech understanding deficits. Scandinavian Audiology, 29(3), 131-138.

Amlani, A. M., Punch, J. L., \& Ching, T. Y. C. (2002). Methods and applications of the audibility index in hearing aid selection and fitting. Trends in Amplification, 6(3), 81-129.

ANSI. (1997/R2012). S3. 5-1997, Methods for the calculation of the speech intelligibility index. New York: American National Standards Institute.

Ching, T. Y., Dillon, H., Katsch, R., \& Byrne, D. 
(2001). Maximizing effective audibility in hearing aid fitting. Ear and Hearing, 22(3), 212-224.

DePaolis, R. A., Janota, C. P., \& Frank, T. (1996). Frequency importance functions for words, sentences, and continuous discourse. Journal of Speech, Language, and Hearing Research, 39(4), 714-723.

Dillon, H. (1999). NAL-NL1: A new procedure for fitting non-linear hearing aids. The Hearing Journal, 52(4), 10-12.

Dubno, J. R., Dirks, D. D., \& Ellison, D. E. (1989). Stop-consonant recognition for normal-hearing listeners and listeners with high-frequency hearing loss. I: The contribution of selected frequency regions. The Journal of the Acoustical Society of America, 85(1), 347-354.

Dubno, J. R., Dirks, D. D., \& Morgan, D. E. (1984). Effects of age and mild hearing loss on speech recognition in noise. The Journal of the Acoustical Society of America, 76(1), 87-96.

Dunn, H. K. \& White, S. D. (1940). Statistical measurement on conversational speech. The Journal of the Acoustical Society of America, 11(3), 278-288.

Fletcher, H. \& Galt, R. H. (1950). The perception of speech and its relation to telephony. The Journal of the Acoustical Society of America, 22(2), 89-151.

French, N. R. \& Steinberg, J. C. (1947). Factors governing the intelligibility of speech sounds. The Journal of the Acoustical Society of America, 19(1), 90-119.

Hargus, S. E. \& Gordon-Salant, S. (1995). Accuracy of speech intelligibility index predictions for noisemasked young listeners with normal hearing and for elderly listeners with hearing impairment. Journal of Speech, Language, and Hearing Research, 38(1), 234-243.

Healy, E. W., Yoho, S. E., \& Apoux, F. (2013). Band importance for sentences and words reexamined. The Journal of the Acoustical Society of America,
133(1), 463-473.

Humes, L. E. (1986). An evaluation of several rationales for selecting hearing aid gain. Journal of Speech and Hearing Disorders, 51(3), 272-281.

Humes, L. E. \& Roberts, L. (1990). Speech recognition difficulties of the hearing-impaired elderly The contributions of audibility. Journal of Speech, Language, and Hearing Research, 33(4), 726-735.

Humes, L. E., Coughlin, M., \& Talley, L. (1996). Evaluation of the use of a new compact disc for auditory perceptual assessment in the elderly. Journal of the American Academy of Audiology, 7, 419-427.

Humes, L. E., Watson, B. U., Christensen, L. A., Cokely, C. G., Halling, D. C., \& Lee, L. (1994). Factors associated with individual differences in clinical measures of speech recognition among the elderly. Journal of Speech, Language, and Hearing Research, 37(2), 465-474.

Jerger, J., Jerger, S., Oliver, T., \& Pirozzolo, F. (1989). Speech understanding in the elderly. Ear and Hearing, 10(2), 79-89.

Jin, I. K., Kates, J. M., \& Arehart, K. H. (2014). Dynamic range for speech materials in korean, english, and mandarin: A cross-language comparison. Journal of Speech, Language, and Hearing Research, 57(5), 2024-2030.

Kamm, C. A., Dirks, D. D., \& Bell, T. S. (1985). Speech recognition and the articulation index for normal and hearing-impaired listeners. The Journal of the Acoustical Society of America, 77(1), 281-288.

Keidser, G., Dillon, H. R., Flax, M., Ching, T., \& Brewer, S. (2011). The NAL-NL2 prescription procedure. Audiology Research, 1(1), 24.

Killion, M. C. \& Mueller, H. G. (2010). Twenty years later: A NEW count-the-dots method. The Hearing Journal, 63(1), 10-12.

Killion, M. C., Mueller, H. G., Pavlovic, C. V., \& Humes, L. E. (1993). A is for audibility. The 
Hearing Journal, 46(4), 29-32.

Kim, M. \& Pae, S. (2007). The international guide to speech acquisition: Korean speech acquisition. Clifton Park, NY: Thomson Delmar Learning.

Kryter, K. D. (1962). Methods for the calculation and use of the articulation index. The Journal of the Acoustical Society of America, 34(11), 1689-1697.

Mueller, H. G. \& Killion, M. C. (1990). An easy method for calculating the articulation index. The Hearing Journal, 43(9), 14-17.

Pavlovic, C. V. (1984). Use of the articulation index for assessing residual auditory function in listeners with sensorineural hearing impairment. The Journal of the Acoustical Society of America, 75(4), 1253-1258.

Pavlovic, C. V. \& Studebaker, G. A. (1984). An evaluation of some assumption underlying the articulation index. The Journal of the Acoustical Society of America, 75(5), 1606-1612.

Pavlovic, C. V., Studebaker, G. A., \& Sherbecoe, R. L. (1986). An articulation index based procedure for predicting the speech recognition performance of hearing-impaired individuals. The Journal of the Acoustical Society of America, 80(1), 50-57.

Rankovic, C. M. (1991). An application of the articulation index to hearing aid fitting. Journal of Speech, Language, and Hearing Research, 34(2), 391-402.

Schum, D. J., Matthews, L. J., \& Lee, F. S. (1991). Actual and predicted word-recognition performance of elderly hearing-impaired listeners. Journal of Speech, Language, and Hearing Research, 34(3), 636-642.

Smit, A. B. (2007). The international guide to speech acquisition: General American English speech acquisition. Clifton Park, NY: Thomson Delama Learning.

Studebaker, G. A. (1992). The effect of equating loudness on audibility-based hearing aid selection procedures. Journal of the American Academy of Audiology, 3(2), 113-118.

Studebaker, G. A. \& Sherbecoe, R. L. (1991). Frequencyimportance and transfer functions for recorded CID W-22 word lists. Journal of Speech, Language, and Hearing Research, 34(2), 427-438.

Studebaker, G. A., Sherbecoe, R. L., \& Gilmore, C. (1993). Frequency-importance and transfer functions for the Auditec of St. Louis recordings of the NU-6 word test. Journal of Speech, Language, and Hearing Research, 36(4), 799-807.

Studebaker, G. A., Sherbecoe, R. L., McDaniel, D. M., \& Gray, G. A. (1997). Age-related changes in monosyllabic word recognition performance when audibility is held constant. Journal of the American Academy of Audiology, 8, 150-162.

Wong, L. L. N., Ho, A. H., Chua, E. W., \& Soli, S. D. (2007). Development of the Cantonese speech intelligibility index. The Journal of the Acoustical Society of America, 121(4), 2350-2361. 